\title{
Molecular Identification and Phylogenetic Grouping of Diaporthe phaseolorum and Phomopsis longicolla Isolates from Soybean
}

\author{
A. W. Zhang, L. Riccioni, W. L. Pedersen, K. P. Kollipara, and G. L. Hartman
}

First, third, fourth, and fifth authors: Department of Crop Sciences, University of Illinois at Urbana-Champaign, Urbana 61801-4723; second author: Istituto Sperimentale per la Patologia Vegetale, Rome; and fifth author: United States Department of Agriculture-Agricultural Research Service, Urbana, IL 61801-4723.

Accepted for publication 30 August 1998.

\begin{abstract}
Zhang, A. W., Riccioni, L., Pedersen, W. L., Kollipara, K. P., and Hartman, G. L. 1998. Molecular identification and phylogenetic grouping of Diaporthe phaseolorum and Phomopsis longicolla isolates from soybean. Phytopathology 88:1306-1314.

Diaporthe phaseolorum and Phomopsis longicolla isolates from soybean were examined using traditional mycological characteristics and molecular methods. Cultural characteristics including types of fruiting bodies and conidia were assessed for isolates collected from soybean stems and seeds. Cultures were identified as $P$. longicolla, D. phaseolorum var. caulivora, D. phaseolorum var. meridionalis, or D. phaseolorum var. sojae. Molecular markers for these groups were developed and analyzed using polymerase chain reaction restriction fragment length polymorphisms (PCRRFLP) and DNA sequencing in the internal transcribed spacer (ITS) and the 5.8S ribosomal DNA. The ITS 4 and $\mathrm{ITS}_{5}$ primers amplified PCR products for all isolates studied. Gel electrophoresis of undigested PCR products and DNA sequencing produced various fragment lengths including $604 \mathrm{bp}$ for $P$. longicolla, 602 and 603 bp for $D$. phaseolorum var. caulivora, $603 \mathrm{bp}$ for $D$. phaseolorum var. meridionalis, and from 597 to $609 \mathrm{bp}$ for $D$. phaseolorum var. sojae. Digestion of these PCR products with enzymes AluI, $H h a \mathrm{I}, M s e \mathrm{I}, R s a \mathrm{I}$, and $S c r$ FI resulted in distinct bands for identification

of P. longicolla and the varieties of D. phaseolorum I. All P. longicolla, $D$. phaseolorum var. caulivora, and D. phaseolorum var. meridionalis isolates were distinguished using $A l u \mathrm{I}$ and $H h a \mathrm{I}$ with $R s a \mathrm{I}$ or $S c r F I$. The banding patterns of $D$. phaseolorum var. sojae isolates were complex and were separated into 11 subgroups after digestion with $A l u \mathrm{I}, H h a \mathrm{I}$, MseI, RsaI, and ScrFI. Phylogenetic analysis of 20 isolates of D. phaseolorum and $P$. longicolla based on the DNA sequence of the ITS region resolved six clades termed A, B, C, D, E, and F. Clade A included all sequenced D. phaseolorum var. caulivora isolates, two from Italy and one from the United States. Isolates in clade B were exclusively associated with $D$. phaseolorum var. meridionalis. Clades A and B formed a well-supported monophyletic group. Isolates in clades $\mathrm{C}, \mathrm{D}, \mathrm{E}$, and $\mathrm{F}$ were morphologically defined as isolates of $P$. longicolla, D. phaseolorum var. sojae, and Diaporthe spp. The ITS sequences similarity of seven geographically diverse $P$. longicolla isolates illustrated that $P$. longicolla isolates have a similar genetic background, with some affiliations to some $D$. phaseolorum var. sojae isolates. Morphological characteristics of the isolates along with the terminal clades of the ITS phylogeny suggest that $P$. longicolla is an individual species, $D$. phaseolorum var. caulivora and $D$. phaseolorum var. meridionalis are varieties of $D$. phaseolorum, and $D$. phaseolorum var. sojae is either several varieties of $D$. phaseolorum or possibly several distinct species.
\end{abstract}

Phomopsis seed decay, pod and stem blight, and stem canker of soybean (Glycine $\max$ (L.) Merr.) are three diseases caused by the Diaporthe/Phomopsis complex $(29,39)$. The fungi in this complex are endemic to soybean production areas throughout the world and can cause reductions in stands, yield, and seed quality $(1,3,4,31)$. The causal organisms are Phomopsis longicolla T. W. Hobbs (teleomorph unknown) and three varieties of Diaporthe phaseolorum (Cooke \& Ellis) Sacc. (D. phaseolorum) (anamorph P. phaseoli (Desmaz.) Sacc.): D. phaseolorum var. caulivora K. L. Athow and R. M. Caldwell, D. phaseolorum var. meridionalis Fernandez, and D. phaseolorum var. sojae (S. G. Lehman) Wehmeyer (16,29,30,39).

$P$. longicolla differs from $D$. phaseolorum var. caulivora, $D$. phaseolorum var. meridionalis, and D. phaseolorum var. sojae in its culture characteristics, morphology (does not have a known teleomorph), and causation (primary cause of seed decay) $(20,24,29)$. D. phaseolorum var. sojae has a wider host range and is more vari-

Corresponding author: G. L. Hartman; E-mail address: ghartman@uiuc.edu

Names are necessary to report factually on available data; however, the USDA neither guarantees nor warrants the standard of the product, and the use of the name by the USDA implies no approval of the product to the exclusion of others that may also be suitable.

Publication no. P-1998-1019-02R

This article is in the public domain and not copyrightable. It may be freely reprinted with customary crediting of the source. The American Phytopathological Society, 1998. able in cultural and other characteristics. It is recognized as a variety of $D$. phaseolorum, because it has both $\alpha$ and $\beta$ conidia, pycnidia with short or no pycnidial beaks, and typical perithecia. D. phaseolorum var. sojae is accepted as the main causal agent of pod and stem blight $(25,26)$. The incitant of northern soybean stem canker, $D$. phaseolorum var. caulivora, was first distinguished and named based on its pathogenicity, homothallism, presence of perithecia, and absence of pycnidia. The causal agent of southern soybean stem canker, $D$. phaseolorum var. meridionalis, is closely related to $D$. phaseolorum var. caulivora, but differs in morphology, heat tolerance, and epidemiology (present only the southern United States) $(4,19,22)$.

Some plant-pathogenic groups of fungi, like those in the soybean Diaporthe/Phomopsis complex, have historically been difficult to identify. The identification of Diaporthe/Phomopsis isolates from soybeans has been based on morphological characteristics including color and colony appearance, size and shape of stromata, the ratio and size of $\alpha$ and $\beta$ conidia, and the arrangement and shape of perithecia $(29,39)$. The causal organism often has been identified by the disease it causes on soybeans. The identification of these organisms has been difficult because the morphological characteristics often are too variable to establish the appropriate taxonomic rank (30). Except for random amplified polymorphic DNA (RAPD) analysis that was used to confirm the existence of at least three different subspecific taxa of D. phaseolorum on soybean (16), there has been no other research on the molecular classification of soybean isolates making up the Diaporthe/Phomopsis complex. It is important to understand the phylogenetic relationship of these fungi 
in the Diaporthe/Phomopsis complex to understand more about their diversity and genetic relationship.

The ribosomal RNA genes in fungi vary among species within a genus or among populations (42). Ribosomal RNA are tandemly repeated with 60 to 220 copies per haploid genome in fungi. Each repeat unit contains a copy each of the $18 \mathrm{~S}, 5.8 \mathrm{~S}$, and $28 \mathrm{~S}$ RNAs, and two internal transcribed spacers $\left(\right.$ ITS $_{1}$ and ITS $\left._{2}\right)(9,35)$.

Polymerase chain reaction (PCR) coupled with restriction fragment length polymorphism (RFLP) analysis in the ITS region has been used in fungal taxonomy and phylogenetic studies $(6,8,11,27)$. Molecular differences among Phomopsis spp. have been analyzed by sequencing the amplified ITS region of isolates from different hosts, and it was proposed that the host-based species concept of Phomopsis was not reliable (34).

The objectives of our research were to (i) infer the phylogeny of the Diaporthe/Phomopsis complex on soybean based on the nucleotide sequence divergence in the ITS regions of the ribosomal DNA (rDNA); and (ii) evaluate the potential of the ITS region as genetic markers for species delimitation by comparing sequences, PCR-RFLP banding patterns, and morphological characteristics of the Diaporthe/Phomopsis isolates collected from soybean.

\section{MATERIALS AND METHODS}

Fungal isolates and morphological identification. Isolates of $D$. phaseolorum and P. longicolla were obtained from soybean seeds and stems collected from Argentina, Brazil, People's Republic of China, Italy, Korea, and the United States (Table 1). All isolates were single spored and maintained on potato dextrose agar (PDA) in petri dishes stored at $4^{\circ} \mathrm{C}$.

All isolates were grown on PDA and incubated under 12-h-perday fluorescent light at 22 to $25^{\circ} \mathrm{C}$ for at least 10 days before being identified based on cultural characteristics $(20,29,39)$. Some isolates were grown on autoclaved soybean stems on water agar, and others were inoculated onto soybean plants in the greenhouse to induce fruiting bodies to facilitate identification.

All isolates were tested for pathogenicity on soybean. Soybean seeds of cv. Williams 82 were planted in $10-\mathrm{cm}$-diameter pots in a soil/sand (1:1) mix and thinned to three plants per pot. Nine plants (three pots per replication) with fully expanded unifoliate leaves (12- to 15-day-old- seedlings) were inoculated by spraying a blended mycelial suspension that consisted of $1 \mathrm{~g}$ wet weight of cultures grown on potato dextrose broth (PDB) for 2 to 3 days mixed in $100 \mathrm{ml}$ of double-distilled $\mathrm{H}_{2} \mathrm{O}$. Nine plants were sprayed with distilled water as a control. All plants were placed in a moist chamber for 3 days and then transferred to the greenhouse bench. Plants were sprayed with $2 \%$ paraquat (Gramoxone; Zeneca Corp., Wilmington, DE) 15 days after inoculation to induce plant senescence and the production of fungal fruiting structures on soybean stems. Stems without any symptoms were excised and placed in a moist seed-germination chamber for 2 weeks to observe if fungal fruiting bodies formed. Selected isolates also were inoculated on 15-dayold seedlings in trays ( 80 by $40 \mathrm{~cm}^{2}$ ) with 20 seedlings per tray. A total of 10 seedlings (five plants per two repetitions) were inoculated by placing a mycelial PDA plug $\left(5 \mathrm{~mm}^{2}\right)$ upside down on one cotyledon that was prewounded 2 to $3 \mathrm{~mm}$ from the stem with a razor blade. A PDA plug without mycelia was used as a control. The plants were covered with a plastic dome for 3 days to maintain high humidity and then uncovered. The number of dead plants and the length of stem lesions were recorded 10 days after inoculation.

DNA extraction. Pieces of agar from the margins of actively growing colonies were transferred to $100 \mathrm{ml}$ of PDB. P. longicolla isolates were grown at $24^{\circ} \mathrm{C}$ for $48 \mathrm{~h}$ and $D$. phaseolorum isolates were grown for 96 to $120 \mathrm{~h}$. Mycelia were collected by squeezing the decanted cultures through one layer of Miracloth (Calbiochem, La Jolla, CA). Total genomic DNA was extracted from $1 \mathrm{~g}$ of mycelia using a previously described protocol (5).
PCR amplification and enzymatic digests. The ITS region of the nuclear rDNA from $P$. longicolla, D. phaseolorum var. caulivora, D. phaseolorum var. meridionalis, and D. phaseolorum var. sojae isolates were amplified using primers $\mathrm{ITS}_{4}$ and $\mathrm{ITS}_{5}$. PCRs were performed with a Perkin-Elmer DNA thermal cycler (Perkin-Elmer Cetus, Emeryville, CA) with a reaction mix of $50 \mathrm{mM} \mathrm{KCl} ; 2.5 \mathrm{mM}$ $\mathrm{MgCl}_{2} ; 10 \mathrm{mM}$ Tris- $\mathrm{HCl}$ at $\mathrm{pH} 8.3 ; 0.2 \mathrm{mM}$ each of dTTP, dATP, $\mathrm{dGTP}$, and dCTP; 50 pmol of the primers; 2.5 units of Taq polymerase (Gibco BRL Corp., Grand Island, MD); and $25 \mathrm{ng}$ of genomic DNA in a final volume of $50 \mu \mathrm{l}$. Reactions were run for 1 cycle at $96^{\circ} \mathrm{C}$ for $3 \mathrm{~min}$ and 30 cycles each at $94^{\circ} \mathrm{C}$ for $1 \mathrm{~min}, 55^{\circ} \mathrm{C}$ for $1 \mathrm{~min}$, and $72^{\circ} \mathrm{C}$ for $2 \mathrm{~min}$. The amplification efficiency was checked by agarose gel electrophoresis using $5 \mu \mathrm{l}$ of the PCR products (42).

PCR products from the ITS region were digested with restriction enzymes AluI, MseI, HhaI, RsaI, and ScrFI, according to the manufacturer's recommendations (Gibco BRL Corp. and New England Biolabs, Beverly, MA), using $7 \mu \mathrm{l}$ of the PCR product (approximately 200 to $500 \mathrm{ng}$ of DNA), $1.5 \mu \mathrm{l}$ of buffer (10X), and $6.5 \mu \mathrm{l}$ of double-distilled $\mathrm{H}_{2} \mathrm{O}$ at $37^{\circ} \mathrm{C}$ for 2 to $4 \mathrm{~h}$. Enzyme-digested PCR products were size-fractionated on a mixed agarose gel of $1 \%$ ultra pure agarose (Gibco BRL Corp.) and 1\% 3:1 high resolution blended agarose (Amresco, Solon, $\mathrm{OH}$ ) at $3.5 \mathrm{~V} / \mathrm{cm}$, stained with ethidium bromide, visualized on a UV transilluminator, and photographed. A 1-kb double-stranded DNA ladder (Gibco BRL Corp.) was used as size marker.

DNA sequencing. Seven isolates of $P$. longicolla, three isolates of $D$. phaseolorum var. caulivora, five isolates of $D$. phaseolorum var. meridionalis, eleven isolates of $D$. phaseolorum var. sojae, and one isolate of Diaporthe were chosen to represent the various DNA groups based on the restriction banding patterns (Table 1). PCR products from the ITS regions were size-fractionated on a $1 \%$ agarose gel in Tris-acetate-EDTA buffer. DNA was purified from agarose blocks using the Gel Purification Kit 50 (Qiagen Inc., Chatsworth, CA). Purified DNA was cloned and sequenced as previously described (43). Sequences were checked between complementary strands for reading errors, and ambiguities were resolved if possible. Complete sequences were aligned by multiple alignment within the species using SeqEd (version 1.0.3; Applied Biosystems Division, Foster City, CA) to correct misread residues.

Data analyses. RFLP banding patterns of Diaporthe/Phomopsis isolates representing different RFLP groups were compared and analyzed by gel electrophoresis and restriction maps created from the DNA sequences of the ITS and the 5.8S rDNA by using computer program DNASTAR's LaserGene software (DNASTAR Inc., Madison, WI).

DNA sequences of the $\mathrm{ITS}_{1}$ and $\mathrm{ITS}_{2}$ regions and the 5.8S rDNA from all the taxa were aligned using the CLUSTAL $\mathrm{W}$ program by setting the opening penalties and extension penalties of five and three, respectively, and by using the weighted toggle transitions in the multiple-alignment parameter option (21). This alignment was further examined and slightly optimized manually.

Maximum parsimony analysis of the aligned sequences was conducted using the PAUP program (version 3.1, Illinois Natural History Survey, Champaign). The sequence of Gaeumannomyces graminis (Sacc.) Arx and Oliver (GenBank accession number U17213) was included in the alignment and was used as an outgroup, while the $D$. phaseolorum and $P$. longicolla isolates were considered as an ingroup in the phylogenetic analysis. Alignment gaps were treated as missing data. The distance matrix was computed to estimate the genetic distance among the isolates and to identify the isolates with identical sequences (" 0 " value point in the distance matrix). The Heuristic search procedure was performed with tree bisection-reconnection (TBR) branch swapping, MULPARS, steepest descent, collapse, and ACCTRAN optimization options to identify the most parsimonious tree. Bootstrap analysis (15) with 500 replicates was performed to measure the degree of support for each branch in the strict consensus tree. The decay values (12) were calculated up to five steps longer than the short- 
est tree to determine the robustness of clades found in the most parsimonious trees. The search was limited to five additional steps because of computational constraints (14). The homoplasy measurements including consistency index (CI) (23), retention index (RI), and rescaled consistency (RC) (13) were estimated. The g1 statistic, a measure of skewness of tree-length distribution (18), was computed by generating 10,000 random parsimonious trees using the random tree option of the PAUP program.

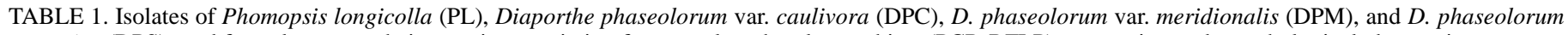
var. sojae (DPS) used for polymerase chain reaction restriction fragment length polymorphism (PCR-RFLP) sequencing and morphological observations

\begin{tabular}{|c|c|c|c|c|}
\hline Code $^{a}$ & Species & Geographic location & Source & $\mathrm{NCBI}_{\text {accession }}{ }^{\mathrm{b}}$ \\
\hline $\mathrm{AK} 76^{*}$ & PL & Arkansas, United States & J. Rupe & AF000206 \\
\hline HO101* & PL & Chunbuk, Korea & E. W. Park & AF000211 \\
\hline 3113 & PL & Illinois, United States & G. L. Hartman & U97658 \\
\hline 3113-1 & PL & Illinois, United States & G. L. Hartman & AF000209 \\
\hline $3114-3$ & PL & Illinois, United States & G. L. Hartman & AF000208 \\
\hline IL3281* & PL & Illinois, United States & G. L. Hartman & \\
\hline $95-\mathrm{VS}-24 *$ & PL & Illinois, United States & G. L. Hartman & \\
\hline IO117* & PL & Iowa, United States & G. L. Hartman & \\
\hline $628 *$ & PL & Italy & A. Porta-Puglia & AF000207 \\
\hline $628 \mathrm{II}$ & PL & Italy & A. Porta-Puglia & AF000210 \\
\hline $632 *$ & PL & Italy & A. Porta-Puglia & \\
\hline $717-F^{*}$ & PL & Italy & A. Porta-Puglia & \\
\hline MO628* & PL & Missouri, United States & G. L. Hartman & \\
\hline MO125* & PL & Missouri, United States & G. L. Hartman & \\
\hline NEB94* & PL & Nebraska, United States & G. L. Hartman & \\
\hline $600 *$ & PL & Ohio, United States & G. L. Hartman & \\
\hline $95-V S-43 *$ & $\mathrm{DPC}$ & Illinois, United States & G. L. Hartman & AF000212 \\
\hline $713 *$ & $\mathrm{DPC}$ & Italy & A. Porta-Puglia & AF000567 \\
\hline $713^{\prime * \mathrm{c}}$ & $\mathrm{DPC}$ & Italy & A. Porta-Puglia & \\
\hline $720 *$ & $\mathrm{DPC}$ & Italy & A. Porta-Puglia & AF000563 \\
\hline $721 *$ & $\mathrm{DPC}$ & Italy & A. Porta-Puglia & \\
\hline DPCA* & $\mathrm{DPC}$ & Italy & A. Porta-Puglia & \\
\hline DPCB* & DPC & Italy & A. Porta-Puglia & \\
\hline DPCC* & $\mathrm{DPC}$ & Italy & A. Porta-Puglia & \\
\hline DPCS1** & $\mathrm{DPC}$ & Italy & A. Porta-Puglia & \\
\hline $\mathrm{DPCS} 2 * *$ & $\mathrm{DPC}$ & Italy & A. Porta-Puglia & \\
\hline $\mathrm{DPCS}^{* *} *$ & $\mathrm{DPC}$ & Illinois, United States & G. L. Hartman & \\
\hline $479 * *$ & $\mathrm{DPC}$ & Illinois, United States & G. L. Hartman & \\
\hline $497 \mathrm{~A} * *$ & $\mathrm{DPC}$ & Illinois, United States & G. L. Hartman & \\
\hline $\mathrm{AG} 1 * *$ & DPM & Argentina & G. L. Hartman & \\
\hline $\mathrm{AG} 2 * *$ & DPM & Argentina & G. L. Hartman & \\
\hline $\mathrm{AG} 3 * *$ & DPM & Argentina & G. L. Hartman & \\
\hline $84-15^{*}$ & DPM & Arkansas, United States & J. Rupe & \\
\hline $90-48^{*}$ & DPM & Arkansas, United States & J. Rupe & AF000564 \\
\hline SDP174* & DPM & Arkansas, United States & J. Rupe & \\
\hline STC-2* & DPM & Arkansas, United States & J. Rupe & AF000566 \\
\hline STC-2’* & DPM & Arkansas, United States & J. Rupe & AF001015 \\
\hline STC-3 & DPM & Arkansas, United States & J. Rupe & AF001016 \\
\hline STC-5* & DPM & Arkansas, United States & J. Rupe & \\
\hline STC-7* & DPM & Arkansas, United States & J. Rupe & \\
\hline STC-8* & DPM & Arkansas, United States & J. Rupe & \\
\hline PMSP1* & DPM & Brazil & D. S. Joccoud Fo. & AF000565 \\
\hline PMSP2* & DPM & Brazil & D. S. Joccoud Fo. & \\
\hline PMSP4** & DPM & Brazil & D. S. Joccoud Fo. & \\
\hline PMSP5** & DPM & Brazil & D. S. Joccoud Fo. & \\
\hline $624 *$ & DPM & Florida, United States & R. Schultheiss & \\
\hline $\mathrm{AK} 25 \mathrm{~A}^{*}$ & DPS & Arkansas, United States & J. Rupe & AF001025 \\
\hline PSSP $2 *$ & DPS & Brazil & D. S. Joccoud Fo. & \\
\hline PSSP4* & DPS & Brazil & D. S. Joccoud Fo. & \\
\hline PSSP5* & DPS & Brazil & D. S. Joccoud Fo. & AF001020 \\
\hline ID102* & DPS & Chunbuk, Korea & E. W. Park & AF001024 \\
\hline KB103* & DPS & Chunbuk, Korea & E. W. Park & \\
\hline SW-93-3* & DPS & Chunbuk, Korea & E. W. Park & \\
\hline SW-93-5* & DPS & Chunbuk, Korea & E. W. Park & \\
\hline SW-93-13* & DPS & Chunbuk, Korea & E. W. Park & AF001018 \\
\hline $473-3^{*}$ & DPS & Italy & A. Porta-Puglia & \\
\hline $473-4 *$ & DPS & Italy & A. Porta-Puglia & AF001021 \\
\hline $714-4^{*}$ & DPS & Italy & A. Porta-Puglia & AF001028 \\
\hline $714-5^{*}$ & DPS & Italy & A. Porta-Puglia & \\
\hline $793-A^{*}$ & DPS & Italy & A. Porta-Puglia & AF001014 \\
\hline $793-B^{*}$ & DPS & Italy & A. Porta-Puglia & AF001019 \\
\hline FAO125* & DPS & Italy & A. Porta-Puglia & AF001017 \\
\hline FAO126* & DPS & Italy & A. Porta-Puglia & AF001022 \\
\hline PRDPS* & DPS & Puerto Rico & G. L. Hartman & AF001023 \\
\hline SW-93-10* & Diaporthe sp. & Chunbuk, Korea & E. W. Park & AF001026 \\
\hline SW-93-11* & Diaporthe sp. & Chunbuk, Korea & E. W. Park & AF001027 \\
\hline
\end{tabular}

a $*=$ isolates demonstrated in PCR-RFLP gel pictures, $* *=$ isolates were used for PCR-RFLP, but not demonstrated in PCR-RFLP gel pictures.

b Accession numbers of sequences submitted to GenBank, National Center of Biotech. Institute.

c Duplicate of isolate 713 . 
Phylogenetic analysis was also performed by the maximum likelihood method (15) using the fastDNAml program (33). Most parsimonious trees were constructed with a transition/transversion ratio of 2.0 default, jumble or random sequence addition order, and global branch swapping options. Distance matrices were also computed and were used to estimate the distance trees using DNADIST and NEIGHBOR programs of the PHYLIP (version 3.5; University of Washington, Seattle).

\section{RESULTS}

Morphological and cultural characteristics. Morphological observations of $D$. phaseolorum and $P$. longicolla isolates were used for the initial classification (Table 1). All P. longicolla isolates produced white mycelia with occasional greenish-yellow surface areas turning light brown with age. Pycnidia usually were in clus- ters, had long beaks, and exuded only $\alpha$ conidia. Black stroma usually were large and widespread, but in some cases were circular, small in diameter ( 2 to $5 \mathrm{~mm}$ ), and few in number.

D. phaseolorum var. meridionalis isolates produced lanose colonies that initially were white-tufted and, 10 to 15 days later, turned tan to buff. Most isolates readily produced pycnidia with $\alpha$ conidia, and a few others either produced perithecia with age or did not produce any fruiting bodies. The underside of cultures was generally tan to buff with brown, irregular-shaped stromas (2 to $10 \mathrm{~mm}$ ) sometimes embedded in the medium. All isolates produced perithecia on soybean stems incubated on water agar.

D. phaseolorum var. caulivora isolates had white, closely appressed mycelia. A few isolates turned light tan with age. As cultures aged, immersed perithecia formed with the tips of their beaks emerged from the medium surface. Stroma were infrequent and small (1 to $2 \mathrm{~mm}$ ), circular, and spread throughout the medium.

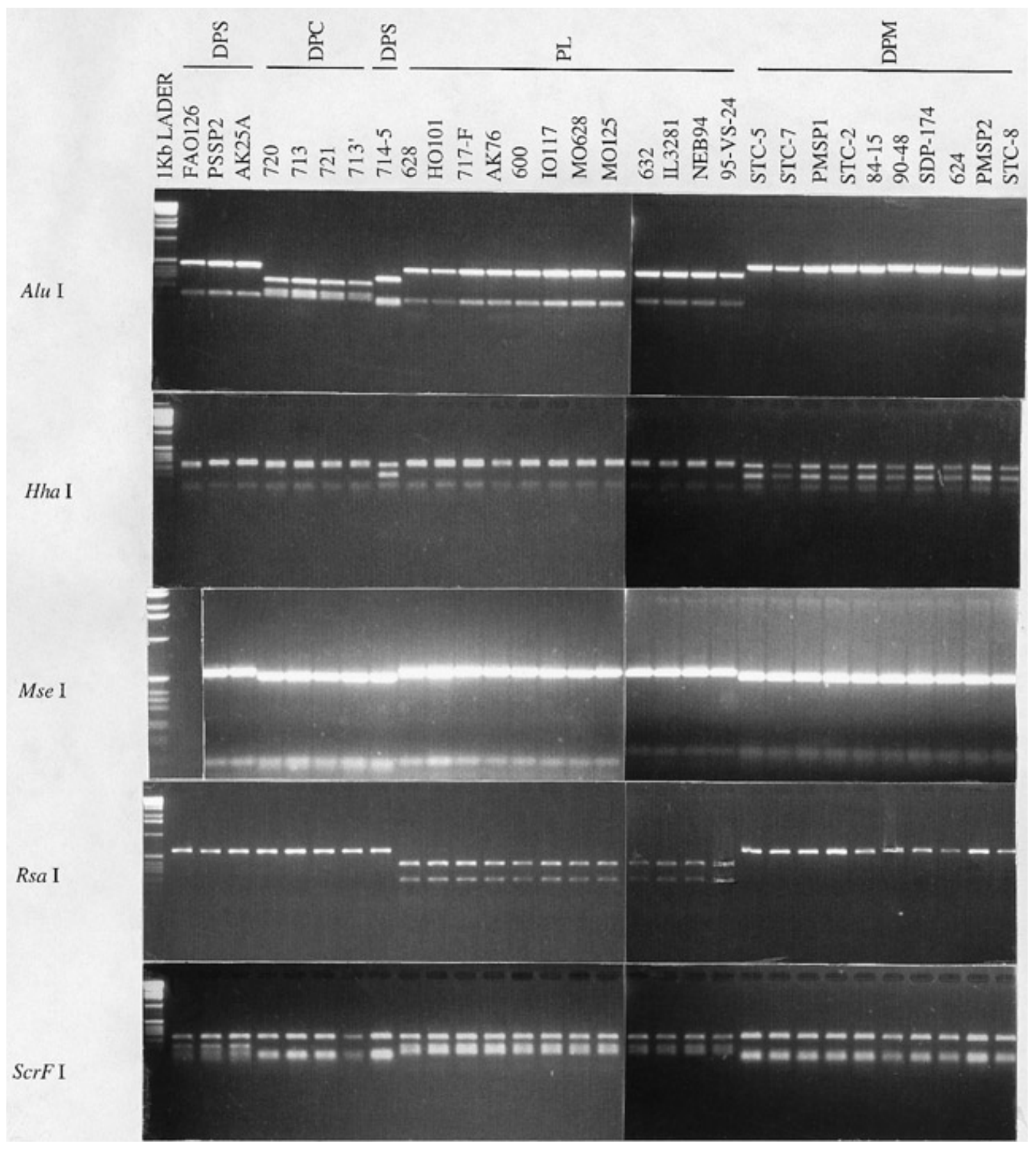

Fig. 1. Restriction banding patterns of polymerase chain reaction-amplified internal transcribed spacer of nuclear ribosomal DNA of Phomopsis longicolla (PL), Diaporthe phaseolorum var. caulivora (DPC), D. phaseolorum var. meridionalis (DPM), and D. phaseolorum var. sojae (DPS) using five restriction enzymes. 
One isolate, DPCA, formed larger, irregular brown stroma immersed in the medium. Most of the isolates produced perithecia on soybean stems incubated on water agar.

Of the isolates identified as $D$. phaseolorum var. sojae, only isolate AK25A produced perithecia on PDA and on soybean stems incubated on water agar. The remaining isolates produced pycnidia and were variable in cultural characteristics. The mycelia were generally floccose and ropelike, but differed in color. Isolates FAO126, ID102, PSSP4, and PSSP5 were white; SW-93-5 was light gray; 473-4 and SW-93-13 were gray brown; 793-A was light brown; 793-B and FAO125 had yellow tufts; and PR D. phaseolorum var. sojae was dark brown. Pycnidia were beakless, solitary, and small or aggregated in large conidiomata. The stroma were usually small ( 2 to $5 \mathrm{~mm}$ ) and scattered, but were circular and larger (5 to $10 \mathrm{~mm}$ ) in isolates FAO125 and very large and irregular in isolates FAO126, ID102, and SW-93-5. All isolates produced $\alpha$ and $\beta$ conidia.

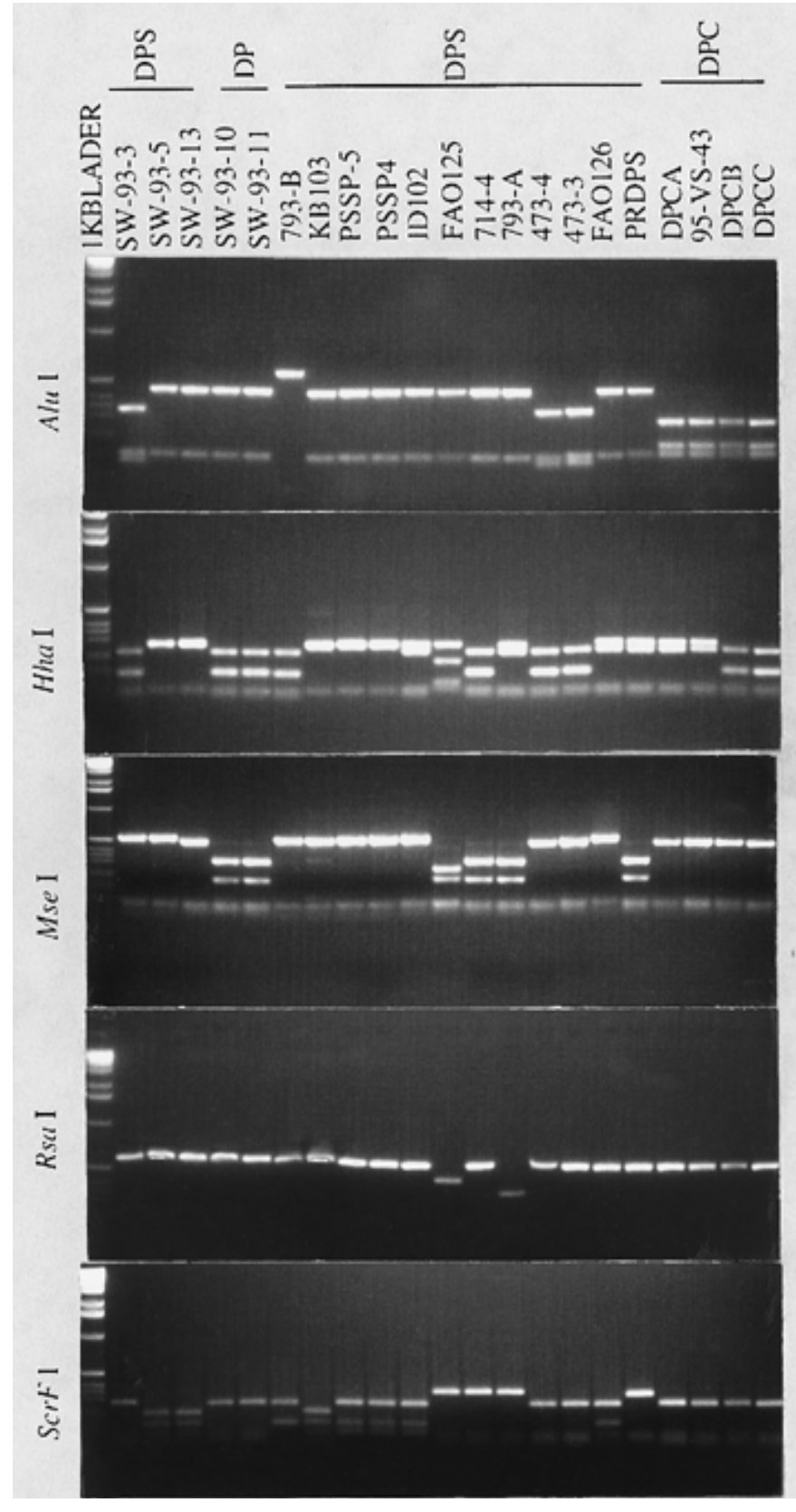

Fig. 2. Restriction banding patterns of polymerase chain reaction-amplified internal transcribed spacer of nuclear ribosomal DNA of Diaporthe phaseolorum var. caulivora (DPC), D. phaseolorum var. sojae (DPS), and Diaporthe spp. using five restriction enzymes.
Isolates SW-93-10 and SW-93-11 were defined as Diaporthe spp. They produced white colonies; scattered, isolated pycnidia with abundant $\alpha$ and $\beta$ conidia; perithecia with long protruding beaks; and nearly colorless undersides with large black $P$. longicolla-like stromata. These isolates did not produce stem blight or stem canker, but perithecia formed on detached stems in a moist chamber and resembled the perithecia produced in PDA.

All $P$. longicolla and D. phaseolorum var. sojae isolates infected stems when soybean plants were spray-inoculated and then treated with paraquat. Pycnidia of $P$. longicolla isolates covered 70 to $90 \%$ of the stem surface, while pycnidia of $D$. phaseolorum var. sojae isolates covered 20 to $90 \%$ of the stem surface. After soybean plants were spray-inoculated and then treated with paraquat, $D$. phaseolorum var. caulivora and $D$. phaseolorum var. meridionalis did not produce any fruiting bodies, while $D$. phaseolorum var. meridionalis isolates produced pycnidia and perithecia only on detached stems under moist incubation. All $D$. phaseolorum var. caulivora and $D$. phaseolorum var. meridionalis isolates produced $0.5-$ to $2-\mathrm{mm}$ lesions on stems after inoculation on wounded cotyledons. D. phaseolorum var. caulivora isolates killed $40 \%$ of the plants after 15 days.

PCR-RFLP. The ITS $_{4}$ and ITS 5 primers amplified PCR products for all isolates studied. Gel electrophoresis of undigested PCR products and DNA sequencing produced various fragment lengths including 604 bp for P. longicolla, 602 and 603 bp for D. phaseolorum var. caulivora, 603 bp for D. phaseolorum var. meridionalis, and from 597 to $609 \mathrm{bp}$ for D. phaseolorum var. sojae. Digestion of these PCR products with enzymes AluI, HhaI, MseI, RsaI, and $S c r F I$ resulted in distinct bands for identification of $P$. longicolla and varieties of $D$. phaseolorum. All $P$. longicolla, $D$. phaseolorum var. caulivora, and D. phaseolorum var. meridionalis isolates were distinguished using AluI and HhaI with RsaI or ScrFI. Enzyme HhaI separated $D$. phaseolorum var. caulivora into two groups. Isolate AK25A had typical D. phaseolorum var. sojae morphological characteristics and was classified as one RFLP subgroup along with isolate PSSP2 (Figs. 1 and 2). Estimated restriction fragment lengths using the DNA sequences of the ITS and the 5.8S region of rDNA for selected RFLP marker bands of Diaporthe/Phomopsis isolates representing each RFLP groups are listed (Table 2). With RFLP marker bands, Diaporthe isolates SW-93-10 and SW-93-11 were separated into one RFLP group. The banding patterns of $D$. phaseolorum var. sojae isolates were complex and could be separated into 11 subgroups after they were digested with the five enzymes. Among these D. phaseolorum var. sojae isolates, three isolates appeared in D. phaseolorum var. sojae subgroups I and $\mathrm{K}$, and only one or two isolates occurred in the other D. phaseolorum var. sojae subgroups.

Phylogenetic analysis. Aligned DNA sequences of the ITS region of all 27 isolates had 632 characters. After checking the pairwise distance matrix created by 27 isolates, six of the seven isolates of $P$. longicolla from Italy, Korea, and the United States and one of the five from D. phaseolorum var. meridionalis (also from the United States) were excluded from the analysis because of $100 \%$ sequence similarity. The pairwise distance analysis of 20 isolates had percentage mean sequence divergence of 0 for $P$. longicolla, 0.002 to 0.183 for $D$. phaseolorum var. caulivora, 0.033 to 23 for D. phaseolorum var. meridionalis, and 0.017 to 58 for $D$. phaseolorum var. sojae (Table 3). Analysis of the entire sequence based on equally weighted character states resulted in five most parsimonious trees with equal lengths of 306 steps. A strict consensus tree was created from the most parsimonious trees using bootstrap and decay values (Fig. 3). The CI and RI of these trees were 0.529 and 0.690 , respectively, when uninformative characters were excluded. The bootstrap values ranged from 57 to $100 \%$ for the consensus clades. When tree length (number of evolutionary steps) of the most parsimonious trees was increased from 306 steps to 311 steps by one-step increments, the number of trees increased from 5 to more than 17,200 (Table 4). The CI, RI, and rescaled CI had inverse linear correlation to the increase in tree length. The g1 statistic calcu- 
lated from 10,000 random trees was -0.6389 . One of the five most parsimonious trees with the number of transitions and transversion swappings for each branch is represented (Fig. 4).

The evolutionary tree constructed by the maximum likelihood method and distance trees estimated by the neighbor joining analysis (data not shown) were very similar in their topologies and were completely congruent with the phylogeny inferred by the maximum parsimony analysis (Figs. 3 and 4 ).

Twenty sequences of $P$. longicolla and $D$. phaseolorum isolates were defined as clades A, B, C, D, E, and F (Fig. 3). Clade A consists of D. phaseolorum var. caulivora isolates, two collected from Italy and one from the United States. Clade B was exclusively associated with $D$. phaseolorum var. meridionalis. D. phaseolorum var. caulivora and $D$. phaseolorum var. meridionalis isolates together formed a monophyletic group with a bootstrap value of 93 and 100 and decay values of +3 and $\geq+5$, respectively. Isolates in clades $\mathrm{C}, \mathrm{D}, \mathrm{E}$, and $\mathrm{F}$ were morphologically defined as P. longicolla, D. phaseolorum var. sojae, and Diaporthe sp. Clade $\mathrm{C}$ contained two subclades. Subclade $\mathrm{C}_{1}$ included $D$. phaseolorum var. sojae isolates 473-4 and SW-93-13 and was strongly supported by a bootstrap value of 100 and $\geq+5$ decay value; subclade $\mathrm{C}_{2}$ included D. phaseolorum var. sojae isolates FAO125 and PR D. phaseolorum var. sojae. Diaporthe isolate SW-93-10 alone formed clade D. Clade E had two D. phaseolorum var. sojae

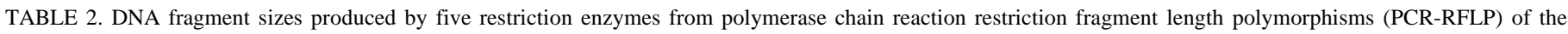

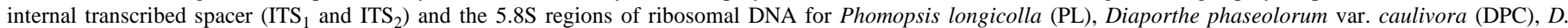
phaseolorum var. meridionalis (DPM), and D. phaseolorum var. sojae (DPS) isolates from soybean

\begin{tabular}{|c|c|c|c|c|c|c|c|}
\hline \multirow[b]{2}{*}{ Fungus } & \multirow{2}{*}{$\begin{array}{l}\text { Sub- } \\
\text { group }^{a}\end{array}$} & \multirow[b]{2}{*}{ Isolate } & \multicolumn{5}{|c|}{ Restriction enzyme $^{b}$} \\
\hline & & & $A l u \mathrm{I}$ & RsaI & HhaI & MseI & ScrFI \\
\hline PL & $\cdots$ & $\begin{array}{l}\text { AK76, HO101, 3113, 3113-1, } \\
\text { 3114-3, IL3281, 95-VS-24, IO117, } \\
\text { 628, 628II, 632, 717-F, MO628, } \\
\text { MO125, NEB94, 600* }\end{array}$ & $458 *, 146^{*}$ & $394 *, 210 *$ & $260 *, 228 *, 61,46,9$ & $526^{*}, 57,21$ & $254^{*}, 147^{*}, 107 *, 96$ \\
\hline DPM & $\ldots$ & $\begin{array}{l}\text { AG1, AG2, AG3, 84-15, 90-48, } \\
\text { SDP174, STC-2, STC-2', STC-3, } \\
\text { STC-5, STC-7, STC-8, PMSP1, } \\
\text { PMSP2, PMSP4, PMSP5, } 624\end{array}$ & $603 *$ & $603 *$ & $228^{*}, 135^{*}, 122,63,46,9$ & $484 *, 57,41,21$ & $265^{*}, 96^{*}, 69^{*}, 66,63,43$ \\
\hline \multirow[t]{2}{*}{ DPC } & A & $\begin{array}{l}\text { DPCA, DPDS1, DPCS2, DPCS3, } \\
\text { 497A, 479, 95-VS-43, 713, 713', } \\
\text { 720, } 721\end{array}$ & $281^{*}, 176^{*}, 146^{*}$ & $603 *$ & $260^{*}, 226^{*}, 62,46,9$ & $484^{*}, 57,41,21$ & $254^{*}, 96^{*}, 77,70,63,43$ \\
\hline & $\mathrm{B}$ & $\mathrm{DPCB}, \mathrm{DPCC}$ & $281^{*}, 176^{*}, 145^{*}$ & $602 *$ & $228^{*}, 134^{*}, 122,63,46,9$ & $484^{*}, 57,40,21$ & $254 *, 96 *, 76,70,63,43$ \\
\hline \multirow[t]{11}{*}{ DPS } & A & $473-3,473-4$ & $339^{*}, 146^{*}, 124^{*}$ & $609 *$ & $228^{*}, 134^{*}, 129,63,46,9$ & $490^{*}, 57,41,21$ & $250 *, 96^{*}, 79,70,69,43$ \\
\hline & $\mathrm{B}$ & $714-4$ & $459^{*}, 144^{*}$ & $603^{*}$ & $227^{*}, 132 *, 126,63,46,9$ & $306^{*}, 181^{*}, 58,38,20$ & $330 *, 95,70,65,43$ \\
\hline & $\mathrm{C}$ & 793-a & $459^{*}, 144^{*}$ & $393^{*}, 210^{*}$ & $260^{*}, 224^{*}, 63,46,9$ & $306^{*}, 181^{*}, 58,38,20$ & $332 *, 95^{*}, 70^{*}, 63,43$ \\
\hline & $\mathrm{D}$ & 793-b & $597 *$ & $597 *$ & $225^{*}, 131^{*}, 126^{*}, 62,44,9$ & $509 *, 57,21$ & $253^{*}, 200^{*}, 144^{*}$ \\
\hline & $\mathrm{E}$ & AK25A, PSSP2 & $459^{*}, 145^{*}$ & $604 *$ & $272^{*}, 261^{*}, 62,9$ & $525^{*}, 58,21$ & $255^{*}, 145^{*}, 95^{*}, 67^{*}, 42$ \\
\hline & $\mathrm{F}$ & FAO125 & $459^{*}, 144^{*}$ & $481^{*}, 122^{*}$ & $261^{*}, 179 *, 90 *, 63,9$ & $247^{*}, 181^{*}, 58,56,41,20$ & $332 *, 95 *, 70 *, 63,43$ \\
\hline & G & FAO126 & $460^{*}, 146^{*}$ & $606^{*}$ & $260 *, 229 *, 63,45,9$ & $528^{*}, 58,20$ & $250^{*}, 154^{*}, 95^{*}, 64,43$ \\
\hline & $\mathrm{H}$ & PRDPS & $456^{*}, 146^{*}$ & $602 *$ & $260^{*}, 225^{*}, 62,46,9$ & $301^{*}, 181^{*}, 59,41,20$ & $315^{*}, 95^{*}, 79^{*}, 70,43$ \\
\hline & $\mathrm{I}$ & ID102, PSSP4, PSSP5 & $457^{*}, 144^{*}$ & $601 *$ & $260^{*}, 226^{*}, 45,61,9$ & $523 *, 58,20$ & $255^{*}, 143^{*}, 108^{*}, 95$ \\
\hline & $\mathrm{J}$ & SW-93-3 & $335^{*}, 146^{*}, 124^{*}$ & $605^{*}$ & $228^{*}, 131^{*}, 130,62,45,9$ & $488^{*}, 58,39,20$ & $267^{*}, 96^{*}, 70^{*}, 65,64,43$ \\
\hline & $\mathrm{K}$ & KB103, SW-93-13, SW-93-5 & $459^{*}, 145^{*}$ & $604 *$ & $272^{*}, 261^{*}, 62,9$ & $488^{*}, 58,39,20$ & $200^{*}, 150^{*}, 95^{*}, 64,52,43$ \\
\hline \multicolumn{8}{|c|}{ Diaporthe } \\
\hline spp. & $\ldots$ & SW-93-10, SW -93-11 & $460^{*}, 146^{*}$ & $606^{*}$ & $225^{*}, 136^{*}, 128,62,46,9$ & $308^{*}, 181^{*}, 58,39,20$ & $255^{*}, 97^{*}, 69^{*}, 66,64,44,11$ \\
\hline
\end{tabular}

a Subgroups of DPC and DPS.

$\mathrm{b} *=$ marker bands used for molecular grouping.

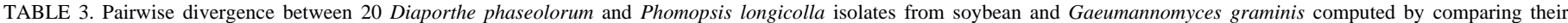
unambiguously aligned sequences ${ }^{\mathrm{a}}$

\begin{tabular}{|c|c|c|c|c|c|c|c|c|c|c|c|c|c|c|c|c|c|c|c|c|c|}
\hline \multirow[b]{2}{*}{ Isolate } & \multicolumn{21}{|c|}{ Isolate code number } \\
\hline & 1 & 2 & 3 & 4 & 5 & 6 & 7 & 8 & 9 & 10 & 11 & 12 & 13 & 14 & 15 & 16 & 17 & 18 & 19 & 20 & 21 \\
\hline 1. $95-\mathrm{VS}-43$ & $\cdots$ & 0.002 & 0.003 & 0.033 & 0.032 & 0.030 & 0.038 & 0.038 & 0.078 & 0.059 & 0.054 & 0.040 & 0.042 & 0.048 & 0.064 & 0.045 & 0.057 & 0.020 & 0.039 & 0.054 & 0.183 \\
\hline 2. 713 & 1 & $\ldots$ & 0.002 & 0.032 & 0.030 & 0.028 & 0.037 & 0.037 & 0.076 & 0.057 & 0.052 & 0.039 & 0.040 & 0.047 & 0.062 & 0.044 & 0.055 & 0.018 & 0.037 & 0.052 & 0.181 \\
\hline 3.720 & 2 & 1 & $\ldots$ & 0.033 & 0.032 & 0.030 & 0.038 & 0.038 & 0.078 & 0.059 & 0.054 & 0.040 & 0.042 & 0.048 & 0.064 & 0.045 & 0.057 & 0.020 & 0.039 & 0.054 & 0.179 \\
\hline 4. $90-48$ & 20 & 19 & 20 & $\ldots$ & 0.002 & 0.003 & 0.005 & 0.050 & 0.079 & 0.067 & 0.066 & 0.049 & 0.055 & 0.055 & 0.077 & 0.054 & 0.065 & 0.037 & 0.044 & 0.067 & 0.172 \\
\hline 5. STC-2 & 19 & 18 & 19 & 1 & $\ldots$ & 0.002 & 0.007 & 0.048 & 0.079 & 0.065 & 0.064 & 0.047 & 0.054 & 0.053 & 0.075 & 0.052 & 0.065 & 0.035 & 0.042 & 0.065 & 0.170 \\
\hline 6. STC-3 & 18 & 17 & 18 & 2 & 1 & $\ldots$ & 0.008 & 0.050 & 0.076 & 0.062 & 0.061 & 0.045 & 0.052 & 0.055 & 0.072 & 0.051 & 0.062 & 0.033 & 0.039 & 0.062 & 0.168 \\
\hline 7. STC-2' & 23 & 22 & 23 & 3 & 4 & 5 & $\ldots$ & 0.053 & 0.079 & 0.069 & 0.061 & 0.054 & 0.060 & 0.057 & 0.080 & 0.057 & 0.067 & 0.042 & 0.049 & 0.070 & 0.175 \\
\hline 8. SW-93-13 & 23 & 22 & 23 & 30 & 29 & 30 & 32 & $\ldots$ & 0.096 & 0.079 & 0.074 & 0.053 & 0.064 & 0.012 & 0.077 & 0.052 & 0.077 & 0.045 & 0.055 & 0.067 & 0.183 \\
\hline 9. 793-B & 46 & 45 & 46 & 47 & 47 & 45 & 47 & 57 & $\ldots$ & 0.057 & 0.057 & 0.098 & 0.083 & 0.098 & 0.071 & 0.099 & 0.062 & 0.078 & 0.091 & 0.064 & 0.188 \\
\hline 10. PSSP5 & 35 & 34 & 35 & 40 & 39 & 37 & 41 & 47 & 34 & & 0.020 & 0.073 & 0.066 & 0.077 & 0.032 & 0.067 & 0.018 & 0.057 & 0.057 & 0.027 & 0.179 \\
\hline 11. ID102 & 32 & 31 & 32 & 39 & 38 & 36 & 36 & 44 & 34 & 12 & $\ldots$ & 0.073 & 0.056 & 0.071 & 0.035 & 0.066 & 0.018 & 0.057 & 0.061 & 0.017 & 0.185 \\
\hline 12. FAO126 & 24 & 23 & 24 & 29 & 28 & 27 & 32 & 32 & 58 & 43 & 43 & $\ldots$ & 0.049 & 0.055 & 0.082 & 0.038 & 0.073 & 0.050 & 0.052 & 0.074 & 0.186 \\
\hline $13.793-\mathrm{A}$ & 25 & 24 & 25 & 33 & 32 & 31 & 36 & 38 & 49 & 39 & 33 & 29 & $\ldots$ & 0.064 & 0.062 & 0.052 & 0.061 & 0.043 & 0.039 & 0.052 & 0.192 \\
\hline 14. $473-4$ & 29 & 28 & 29 & 33 & 32 & 33 & 34 & 7 & 58 & 46 & 42 & 33 & 38 & $\ldots$ & 0.080 & 0.050 & 0.074 & 0.052 & 0.057 & 0.069 & 0.186 \\
\hline 15. FAO126 & 38 & 37 & 38 & 46 & 45 & 43 & 48 & 46 & 42 & 19 & 21 & 49 & 37 & 48 & $\ldots$ & 0.067 & 0.035 & 0.057 & 0.061 & 0.020 & 0.185 \\
\hline 16. PRDPS & 27 & 26 & 27 & 32 & 31 & 30 & 34 & 31 & 58 & 40 & 39 & 23 & 31 & 30 & 40 & $\ldots$ & 0.064 & 0.044 & 0.047 & 0.057 & 0.191 \\
\hline 17. AK25A & 34 & 33 & 34 & 39 & 39 & 37 & 40 & 46 & 37 & 11 & 11 & 43 & 36 & 44 & 21 & 38 & $\ldots$ & 0.059 & 0.059 & 0.023 & 0.187 \\
\hline 18. SW-93-10 & 12 & 11 & 12 & 22 & 21 & 20 & 25 & 27 & 46 & 34 & 34 & 30 & 26 & 31 & 34 & 26 & 35 & $\ldots$ & 0.030 & 0.054 & 0.169 \\
\hline 19. $714-4$ & 23 & 22 & 23 & 26 & 25 & 23 & 29 & 33 & 54 & 34 & 36 & 31 & 23 & 34 & 36 & 28 & 35 & 18 & $\ldots$ & 0.054 & 0.172 \\
\hline 20. AK76 & 32 & 31 & 32 & 40 & 39 & 37 & 42 & 40 & 38 & 16 & 10 & 44 & 31 & 41 & 12 & 34 & 14 & 32 & 32 & $\ldots$ & 0.183 \\
\hline 21. G. graminis & 99 & 98 & 97 & 93 & 92 & 91 & 95 & 99 & 101 & 97 & 100 & 100 & 104 & 101 & 100 & 103 & 101 & 92 & 93 & 99 & $\ldots$ \\
\hline
\end{tabular}

a The absolute distance values are shown in the left side of the diagonal and the percent mean distance values are shown in the right side of the diagonal. 
isolates. Clade F contained the P. longicolla isolate AK76 and some $D$. phaseolorum var. sojae isolates.

\section{DISCUSSION}

The taxonomic status and nomenclature of the Diaporthel Phomopsis complex on soybean has been reviewed (30). D. phaseolorum and $P$. phaseoli were recognized, respectively, as the valid binomials for the teleomorph and anamorph belonging to this complex, while $P$. longicolla was accepted as a separate entity (30). The previous classification of $D$. phaseolorum at the variety level was considered to be unsatisfactory because of the considerable variability in morphology, physiology, and host specificity. Instead, it was proposed that the forma specialis concept should be adopted for intraspecific designations (30). This nomenclature was not accepted $(16,20)$, and the correct usage of names is still an issue. Morphological observations in our study demonstrated that isolates within $P$. longicolla, D. phaseolorum var. caulivora, and D. phaseolorum var. meridionalis have distinguishable characteristics, although morphological identification is often time consuming and not always defined. P. longicolla isolates had black, large, and widely dispersed stroma in agar media. This is an important characteristic to identify isolates of $P$. longicolla, but occasionally we observed some isolates with small (2 to $5 \mathrm{~mm}$ ) and few pycnidia. D. phaseolorum var. sojae isolates varied in cultural characteristics, confirming what has been reported $(16,25,29,30)$. This variation may be explained by its heterothallic nature (41).
To use molecular characteristics for systematic studies, the appropriate molecular markers need to resolve the desired taxonomic level $(16,28,32,38,42)$, showing neither excessive variation nor homogeneity at the rank of interest (7). The ITS region of rDNA has been used to differentiate species and also to differentiate subgroups within species $(10,17,28,37)$. The ITS region includes a $5.8 \mathrm{~S}$ subunit that provided an appropriate length of DNA for observing variation of the Diaporthe/Phomopsis complex in our study. No single enzyme distinguished all $P$. longicolla, $D$. phaseolorum var. caulivora, $D$. phaseolorum var. meridionalis, and $D$. phaseolorum var. sojae isolates; however, three enzymes clearly distinguished $P$. longicolla, D. phaseolorum var. meridionalis, and D. phaseolorum var. caulivora isolates from each other.

Of the Diaporthe and Phomopsis isolates used in this experiment, each $P$. longicolla and $D$. phaseolorum var. meridionalis isolate originated from three different countries, while D. phaseolorum var. caulivora isolates come from two countries (Table 1). The isolates of $P$. longicolla, D. phaseolorum var. caulivora, and D. phaseolorum var. meridionalis have their own uniform PCR-RFLP banding patterns; and the $D$. phaseolorum var. caulivora isolates produced two HhaI digestion patterns. However, isolates within D. phaseolorum var. sojae and Diaporthe spp. were separated into 12 groups. The PCR-RFLP groups generated in our study corresponded morphologically to delineated species of $P$. longicolla, D. phaseolorum var. meridionalis, and D. phaseolorum var. caulivora regardless of the isolates' geographic origins. Based on the PCR-RFLP markers summarized (Table 2; Figs. 1 and 2),

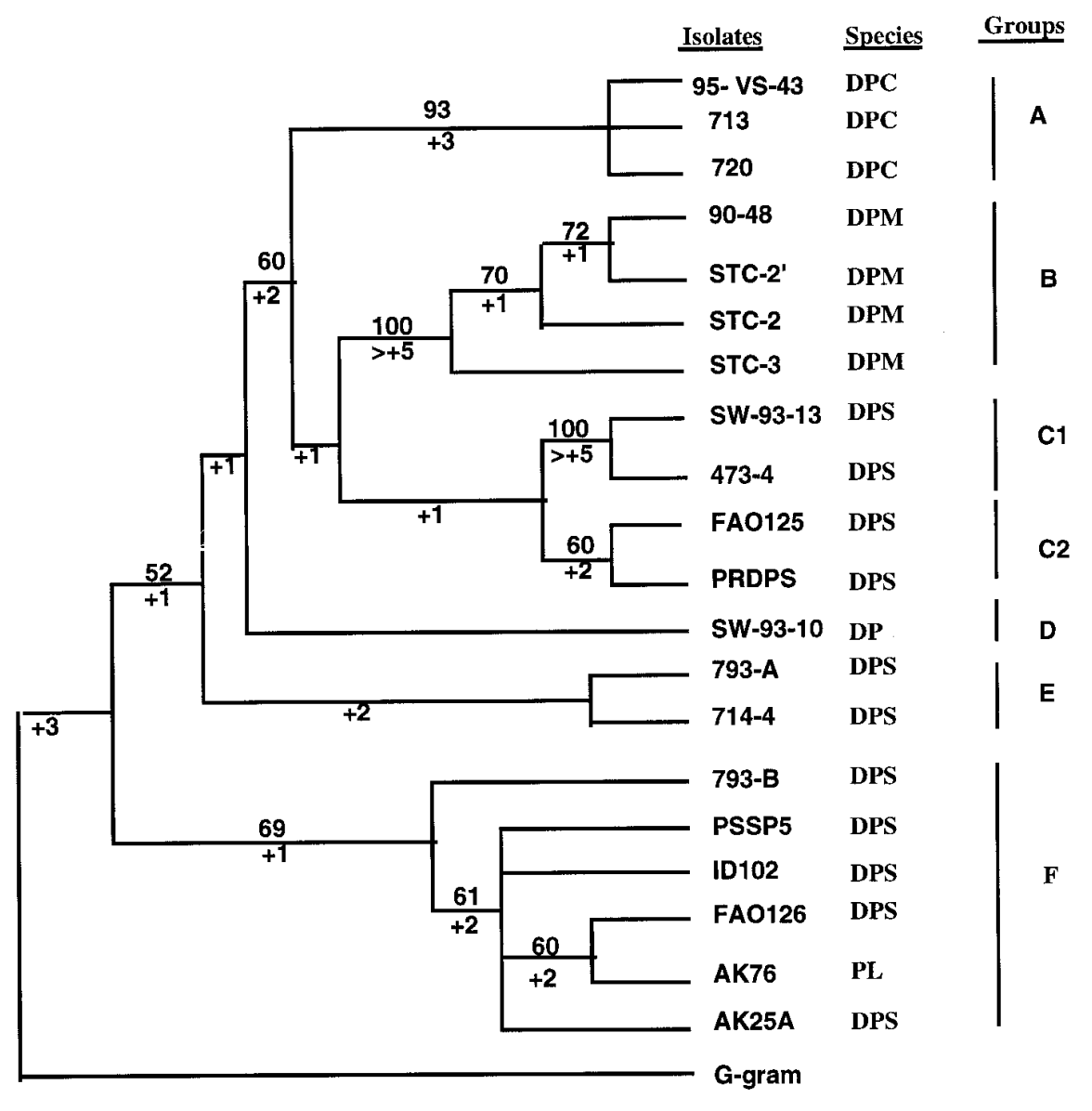

Fig. 3. Strict consensus of the five most parsimonious trees with equal length of 306 steps obtained from equally weighted parsimonious analysis using the branch-and-bound option of the PAUP program of the entire unambiguously aligned internal transcribed spacers region from 20 isolates of Diaporthe phaseolorum and Phomopsis longicolla. The numbers above the branches indicate the number of times a monophylotic group occurred in 500 bootstrap replicates. The numbers shown below the branches indicate the additional number of steps over 306 (the total number of steps in the shortest tree) needed to collapse that branch (decay values). Decay analysis with tree length $\geq$ five steps longer than the most parsimonious trees could not be performed owing to the computational constraints. A, B, $\mathrm{C}_{1}, \mathrm{C}_{2}, \mathrm{D}, \mathrm{E}$, and $\mathrm{F}$ are names of subclades. G-gram $=$ Gaeumannomyces graminis, $\mathrm{PL}=$ Phomopsis longicolla, $\mathrm{DPC}=$ Diaporthe phaseolorum var. caulivora, $\mathrm{DPM}=D$. phaseolorum var. meridionalis, $\mathrm{DPS}=$ D. phaseolorum var. sojae, and DP = Diaporthe phaseolorum. 
Diaporthe and Phomopsis isolates can be identified based on molecular characterization.

Sequence variation of the ITS region has been used to study intraand interspecific divergence. For example, the ITS $_{1}$ sequences among northern hemisphere species of Armillaria were identical, although these species could be differentiated based on interfertility tests, morphology, and other molecular criteria (2). In contrast, ITS sequences were used to separate species among intersterility groups in Pleurotus spp. (40). The differences in ITS sequence divergence among these taxonomic groups of fungi may reflect different rates of ITS sequence evolution, the time frame in which population divergence and speciation occurred, and the time elapsed since speciation. Genetic diversity within Phomopsis and Diaporthe spp. and the validity of the host-based species concept that has prevailed were assayed and tested using the ITS region of rDNA (34). The results of this study disagree with the classification system that identifies Phomopsis spp. based on their hosts. However, isolates used in that study (34) were not morphologically identified to species, and there is insufficient data to determine whether the terminal clades in the ITS phylogeny included one or more species. In our study, four taxonomic groups of $P$. longicolla and $D$. phaseolorum from only soybean isolates were classified to species and variety by traditional morphological methods and their phylogenic relationships based on DNA sequencing.

Phylogenetic analysis of 21 ITS sequences representing each PCR-RFLP banding pattern yielded five equally parsimonious trees. The number of most parsimonious trees obtained can be attributed to the number of terminal units analyzed (14) and to the homoplasy of the ITS sequence data (36). Most of the alternative topologies among the most parsimonious trees occurred at terminal and subterminal clades, particularly in branches supported by relatively few characters. Trees with more than 311 steps could not be examined because of the limitation of the memory capacity in the PAUP program tree buffer. The g1 statistic calculated from 10,000 random trees was -0.6389 , indicating that the tree length distribution was significantly skewed to the left (negative value), suggesting a strong phylogenetic signal in the data.

The sequence alignment result showed that Italian $D$. phaseolorum var. caulivora varied in the ITS region. This indicates that there are genetic differences among the $D$. phaseolorum var. caulivora isolates from one area. The same occurred within the $D$. phaseolorum var. meridionalis isolates in clade B; even though all isolates originated from one area in the United States, the sequences varied. It seems possible that $D$. phaseolorum var. caulivora and D. phaseolorum var. meridionalis, which both cause soybean stem canker, together with some $D$. phaseolorum var. sojae may have originated from a common ancestor. An unusual aspect of stem canker is that $D$. phaseolorum var. caulivora and D. phaseolorum var. meridionalis colonize all soybean cultivars, but disease only develops on susceptible cultivars (3). Selection pressure due to deployment of resistant host cultivars may have increased genetic diversity within isolates of D. phaseolorum var. caulivora and D. phaseolorum var. meridionalis.

P. longicolla isolate AK76 showed a close relationship to $D$. phaseolorum var. sojae isolate AK25A and formed a moderately supported subclade (59\% bootstrap value and +2 decay index)

TABLE 4. Decay analysis of DNA sequences of the internal transcribed spacer region of 20 Diaporthe phaseolorum and Phomopsis longicolla isolates using Heuristic search of the PAUP program

\begin{tabular}{lrccc}
\hline $\begin{array}{l}\text { Tree length in } \\
\text { no. of steps }\end{array}$ & $\begin{array}{c}\text { Total no. of } \\
\text { trees found }\end{array}$ & $\begin{array}{c}\text { Consistency } \\
\text { index }\end{array}$ & $\begin{array}{c}\text { Retention } \\
\text { index }\end{array}$ & $\begin{array}{c}\text { Rescaled } \\
\text { consistency }\end{array}$ \\
\hline 306 & 5 & 0.529 & 0.690 & 0.469 \\
$\leq 307$ & 41 & 0.526 & 0.687 & 0.465 \\
$\leq 308$ & 203 & 0.675 & 0.684 & 0.462 \\
$\leq 309$ & 1,654 & 0.673 & 0.680 & 0.458 \\
$\leq 310$ & 7,409 & 0.671 & 0.677 & 0.454 \\
$\leq 311$ & $>17,200$ & 0.669 & 0.674 & 0.451 \\
\hline
\end{tabular}

with the isolate FAO126. This isolate was classified as D. phaseolorum var. sojae, even though it showed similar cultural characteristics to $P$. longicolla isolates including absence of a Diaporthe stage, white mycelium, $\alpha$ conidia, extensive black stroma, few $\beta$ conidia, and pycnidia with long beaks. D. phaseolorum var. sojae appeared to be a polyphyletic taxon, having some isolates associated with the $D$. phaseolorum var. caulivora and some with the D. phaseolorum var. meridionalis clades. However, this association was poorly supported by $<50 \%$ bootstrap values. Instead of the three $D$. phaseolorum varieties being closely related to each other, the phylogenetic analysis of the ITS sequences indicate that the $P$. longicolla and some $D$. phaseolorum var. sojae have a closer relationship. Similar conclusions were made in another study (16) using the morphology of soybean Diaporthe and Phomopsis isolates and RAPD analysis. D. phaseolorum var. sojae contains greater genetic variability than any other species or varieties studied (Fig. 3).

The similarity of ITS sequences of the seven P. longicolla isolates representing different geographic distributions illustrates a uniform genetic background among $P$. longicolla isolates. Viewed as the prevalent causal organism of Phomopsis seed decay (3), $P$. longicolla has been distributed worldwide with the dissemination of soybean seeds. P. longicolla does not have a known teleomorph $(20,24,25)$, which may account for its apparent genetic uniformity.

Previous studies based on morphological observations offered many criteria to identify and classify various isolates of the Diaporthel Phomopsis complex. By using PCR-RFLP, we were able to separate $P$. longicolla, $D$. phaseolorum var. caulivora, D. phaseolorum

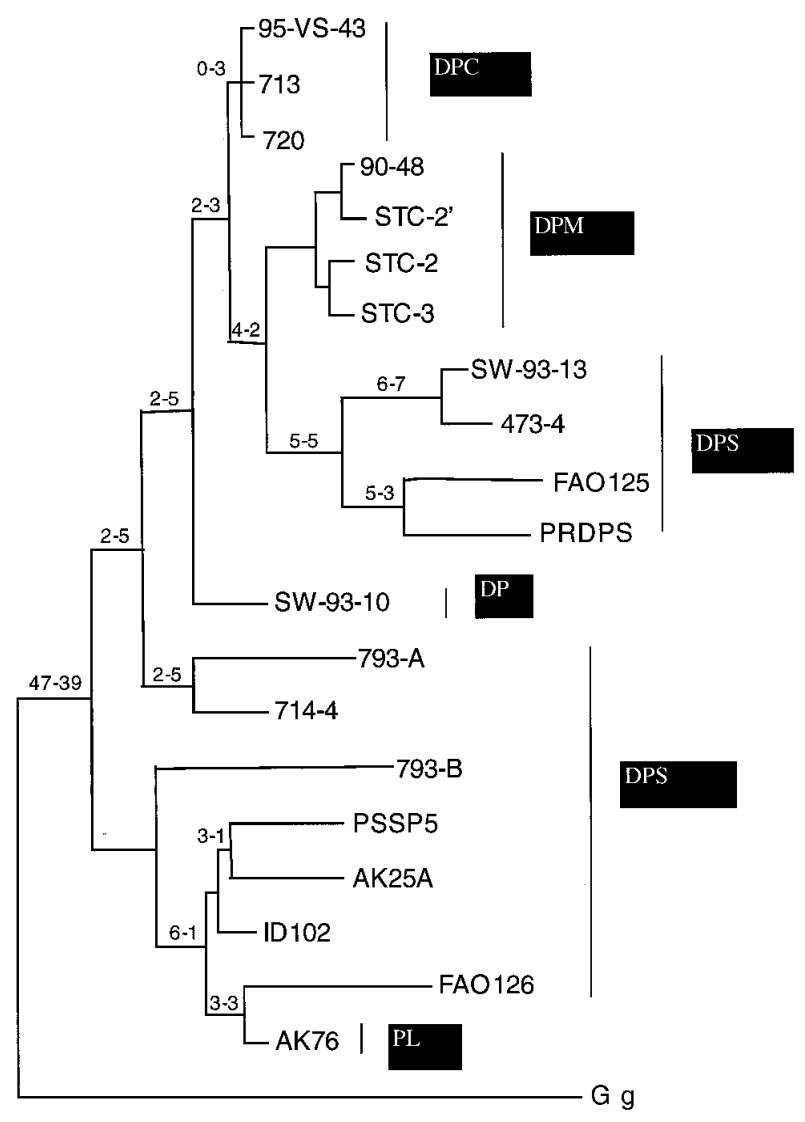

Fig. 4. One of the five most parsimonious trees with a length of 306 steps from equally weighted parsimony analysis of the entire unambiguously aligned internal transcribed spacers region from 20 isolates of Diaporthe phaseolorum and Phomopsis longicolla. The pairs of numbers separated by a hyphen refer to the number of transitions-transversions supporting that branch. G $\mathrm{g}=$ Gaeumannomyces graminis, $\mathrm{PL}=$ Phomopsis longicolla, $\mathrm{DPC}=$ Diaporthe phaseolorum var. caulivora, $\mathrm{DPM}=D$. phaseolorum var. meridionalis, $\mathrm{DPS}=D$. phaseolorum var. sojae, and DP = Diaporthe phaseolorum . 
var. meridionalis, and $D$. phaseolorum var. sojae isolates faster. This method could be used for routine identification of these fungi. Isolates associated with terminal clades in the ITS phylogeny suggests that $P$. longicolla is a single species. $D$. phaseolorum var. caulivora and $D$. phaseolorum var. meridionalis are two varieties of $D$. phaseolorum, while $D$. phaseolorum var. sojae may be divided into several varieties or even distinct species.

\section{ACKNOWLEDGMENTS}

The participation of L. Riccioni was supported by the minister per le. Project No. 451, Area 10. We thank W. D. Chen, J. B. Sinclair, and L. Vaillancourt for their critical suggestions and for reviewing this manuscript; G. Concaí and R. L. Ma for skilled technical assistance; and D. S. Joccound Fo., A. Porta-Puglia, J. Rupe, R. Schultheiss, and E. W. Park for Phomopsis and Diaporthe isolates.

\section{LITERATURE CITED}

1. Abney, T. S., and Ploper, L. D. 1988. Seed diseases. Pages 3-6 in: Soybean Diseases of the North Central Region. T. D. Wyllie and D. H. Scott, eds. The American Phytopathological Society, St. Paul, MN.

2. Anderson, J. B., and Stasovske, E. 1992. Molecular phylogeny of northern hemisphere species of Armillaria. Mycologia 84:505-516.

3. Anderson, T. R. 1994. Incidence of pod and seed infection in two soybean lines differing in resistance to Phomopsis seed decay. Can. J. Plant Sci. 95:543-545.

4. Backman, P. A., Weaver, D. B., and Morgan-Jones G. 1985. Soybean stem canker: An emerging disease problem. Plant Dis. 69:641-647.

5. Beck, J. J., and Ligon, J. M. 1995. Polymerase chain reaction assays for the detection of Stagonospora nodorum and Septoria tritici in wheat. Phytopathology 85:319-324.

6. Bruns, T. D., White, T. J., and Taylor, J. W. 1991. Fungal molecular systematics. Annu. Rev. Ecol. Syst. 22:525-564.

7. Buchko, J., and Klassen, G. R. 1990. Detection of length heterogeneity in the ribosomal DNA of Pythium ultimum by PCR amplification of the intergenic region. Curr. Genet. 18:203-205.

8. Buscot, F., Wipf, D., Di Battista, C., Munch, J. C., Botton, B., and Martin, F. 1996. DNA polymorphism in morels: PCR/RFLP analysis of the ribosomal DNA spacer and micro satellite-primed PCR. Mycol. Res. 100:63-71.

9. Cassidy, J. R., Moore, D., Lu, B. C., and Pukkila, P. J. 1984. Unusual organization and lack of recombination in the ribosomal RNA genes of Coprinus cinereus. Curr. Genet. 8:607-613.

10. Chen, W. D., Gray, L. E., and Grau, C. R. 1996. Molecular differentiation of fungi associated with brown stem rot and detection of Phialophora gregata in resistant and susceptible soybean cultivars. Phytopathology 86:1140-1148.

11. Chen, W. D., and Hoy, J. W. 1993. Molecular and morphological comparison of Pythium arrhenomanes and P. graminicola. Mycol. Res. 97:1371-1378.

12. Donoghue, M. J., Olmstead, R. G., Smith, J. F., and Palmer, J. D. 1992. Phylogenetic relationships of Dipsacales based on rbcL sequences. Ann. Mo. Bot. Gard. 79:333-345.

13. Farris, J. S. 1989. The retention index and homoplasy excess. Syst. Zool. 38:406-407.

14. Felsenstein, J. 1978. The number of evolutionary trees. Syst. Zool. 27: 401-410.

15. Felsenstein J. 1981. Confidence limits on phylogenies and approach maximum likelihood. J. Mol. Evol. 17:368-376.

16. Fernandez, F. A., and Hanlin, R. T. 1996. Morphological and RAPD analysis of Diaporthe phaseolorum from soybean. Mycologia 88:425-440.

17. Goodwin, P. H., Kirkpatrick, B. C., and Dunoway, J. M. 1989. Cloned DNA probes for identification of Phytophthora parasitica. Phytopathology 79:716-721.

18. Hillism, D. M., and Huelsenbeck, J. P. 1992. Signal, noise, and reliability in molecular phylogenetic analyses. J. Hered. 83:189-195.

19. Hobbs, T. W., and Philips, D. V. 1985. Identification of Diaporthe and Phomopsis isolates from soybean. (Abstr.) Phytopathology 75:500.

20. Hobbs, T. W., Schmitthenner, A. F., and Kuter, G. A. 1985. A new Phomopsis species from soybean. Mycologia 77:535-544.
21. Julie, D. T., Desmond, G. H., and Toby, J. G. 1994. Clustal W: Improving the sensitivity of progressive multiple sequence alignment through sequence weighting, position specific gap penalties, and weight matrix choice. Nucleic Acids Res. 22:4673-4680.

22. Keeling, B. L. 1988. Influence of temperature on growth and pathogenicity of geographical isolates of Diaporthe phaseolorum var. caulivora. Plant Dis. $72: 220-222$

23. Kluge, A. G., and Farris, J. S. 1969. Quantitative phylogenetics and the evolution of anurans. Syst. Zool. 18:1-32.

24. Kmetz, K. T., Elett, C. W., and Schnitthenner, A. F. 1974. Isolation of seedborne Diaporthe phaseolorum and Phomopsis from immature soybean plants. Plant Dis. Rep. 58:978-982.

25. Kulik, M. M. 1984. Symptomless infection, persistence, and production of pycnidia in host and non-host plants by Phomopsis batatae, Phomopsis phaseoli and Phomopsis sojae, and the taxonomic implications. Mycologia 76:274-291.

26. Luttrell, E. S. 1947. Diaporthe phaseolorum var. sojae on crop plants. Phytopathology 37:445-465.

27. Maes, M., Garbeva, P., and Kamoen, O. 1996. Recognition and detection in seed of the Xanthomonas pathogens that cause cereal leaf streak using rDNA spacer sequences and polymerase chain reaction. Phytopathology 86:63-39.

28. Martin, F. N. 1990. Variation in the ribosomal DNA repeat unit within single-oospore isolates of the genus Pythium. Genome 33:585-591.

29. Morgan-Jones, G. 1985. The Diaporthe/Phomopsis complex of soybean: Morphology. Pages 1-7 in: Proceedings of the Conference on Diaporthel Phomopsis Disease Complex of Soybean. U.S. Dep. Agric., Beltsville, MD.

30. Morgan-Jones, G. 1985. The Diaporthe/Phomopsis complex: Taxonomic considerations. Pages 1699-1706 in: Proceedings of the World Soybean Research Conference IV. A. Pascale. ed. Orientación Gráfica Editora, Buenos Aires.

31. Mulrooney, R. P. 1988. Soybean disease loss estimate for southern United States in 1987. Plant Dis. 70:600-602.

32. O'Donnell, K. 1992. Ribosomal DNA internal transcribed spacers are highly divergent in the phytopathogenic ascomycete Fusarium sambucinum (Gibberella pulicaris). Curr. Genet. 22:213-220.

33. Olsen, G. J., Matsuda, H., Hagstrom, R., and Overbeek, R. 1994. FastDNAml: A tool for construction of phylogenetic trees of DNA sequences using maximum likelihood. Comput. Appl. Biosci. 10:41-48.

34. Rehner, S. A., and Uecker, F. A. 1994. Nuclear ribosomal internal transcribed spacer phylogeny and host diversity in the coelomycete Phomopsis. Can. J. Bot. 72:1666-1674.

35. Russell, P. J., Hammett, J. R., and Selker, E. U. 1976. Neurospora crassa cytoplasmic ribosomes: Ribosomal ribonucleic acid synthesis in the wild type. J. Bacteriol. 127:785-793.

36. Sandersin, M. J., and Donnoghue, M. J. 1989. Patterns of variation in levels of homopalsy. Evolution 43:1781-1795.

37. Schilling, A. G., Moller, E. M., and Geiger, H. H. 1996. Polymerase chain reaction-based assays for the detection for species-specific detection of Fusarium culmorum, F. graminearum, and F. avenaceum. Phytopathology 86:515-522.

38. Schoen, C. D., Knorr, D., and Leone, G. 1996. Detection of potato leafroll virus in dormant potato tubers by immunocapture and a fluorogenic 5' nuclease RT-PCR assay. Phytopathology 86:993-999.

39. Sinclair, J. B., and Backman, P. A. 1989. Compendium of Soybean Diseases, 3rd ed. The American Phytopathological Society, St. Paul, MN.

40. Vilgalys, R., and Sun, B. L. 1994. Ancient and recent patterns of geographic speciation in the oyster mushroom Pleurotus revealed by phylogenetic analysis of ribosomal DNA sequences. Proc. Natl. Acad. Sci. U.S.A. 91:4599-4603.

41. Welch, A. W., and Gilman, J. C. 1948. Hetero- and homothalic types of Diaporthe on soybeans. Phytopathology 38:628-637.

42. White, T. J., Bruns, T., Lee, S., and Taylor, J. 1990. Amplification and direct sequencing of fungal ribosomal RNA genes for phylogenetics. Pages 315-22 in: PCR-Protocols. A Guide to Methods and Applications. M. A. Innis, D. H. Gelfand, J. J. Sninsky, and T. J. White, eds. Academic Press, Inc., New York.

43. Zhang, A. W., Hartman, G. L., Riccioni, L., Chen, W. D., Ma, R. Z., and Pedersen, W. L. 1997. Polymerase chain reaction to distinguish Diaporthe phaseolorum and Phomopsis longicolla from other soybean fungal pathogens and their detection in soybean tissues. Plant Dis. 81:1143-1149. 